\title{
Frequency and Abundance of Arenicolous Marine Fungi along South Indian Beaches
}

\author{
G. R. Nambiar ${ }^{1}$ and K. Raveendran
}

Department of P.G. Studies \& Research in Botany, Sir Syed College, Kannur, Kerala-670142, India

Received 8 April 2009, accepted in final revised form 31 October 2009

\begin{abstract}
Sand buried wood materials were collected from the beaches of Kerala, Tamil Nadu and Pondicherry and screened for marine fungi. A total of 27 arenicolous marine fungi were encountered including 19 Ascomycetes, 1 Basidiomycete and 7 Mitosporic fungi. The present study records the maximum number of arenicolous marine fungi reported so far. Ceriosporopsis capillacea, Dryosphaera tropicalis and Savoryella appendiculata, are new record for Pondicherry, Corollospora colossa and Corollospora indica from Tamil Nadu and Corollospora gracilis from Kerala.
\end{abstract}

Keywords: Arenicolous; Marine fungi; Wood samples; South India.

(c) 2010 JSR Publications. ISSN: 2070-0237 (Print); 2070-0245 (Online). All rights reserved.

DOI: 10.3329/jsr.v2i1.2580

J. Sci. Res. 2 (1), 138-143 (2010)

\section{Introduction}

Fungi are capable of becoming adapted to every condition of life. Marine fungi are one such microbiota which adapt to the saline environments, most of them require sea water for the successful completion of their life cycle. Many substrates in the natural marine environment are good sources of marine fungi. These comprise of woody tissues, leaves and fruits of marine plants, sea grasses, algae, sea weeds, animal exoskeleton and keratinaceous substrates. Marine mycology is gaining importance not only due to taxonomic and ecological perspective but also for unique metabolites, biochemicals and enzymes from the sea.

Scanty information is available on mycoflora of sand grains in intertidal and subtidal part of sandy beaches [1]. The group of fungi inhabiting sand and growing in water filled spaces between sand grains are referred to as arenicolous marine fungi [2]. They are probably important link in the food web because they breakdown cellulose, which cannot be digested by interstitial organisms.

\footnotetext{
${ }^{1}$ Corresponding author: grn_149@rediffmail.com
} 
Although marine fungal studies were carried out along Indian coast, more emphasis were given to lignicolous and manglicolous marine fungi [3- 26]. The present paper deals with the frequency of occurrence and relative abundance of arenicolous marine fungi along south Indian coast.

\section{Materials and Methods}

\subsection{Collection and treatment of wood materials}

Collections of sand buried wood materials were carried out from the sandy beaches of Kerala (Kovallam and Kannur), Tamil Nadu (Chennai and Kanyakumari) and Pondicherry. Collections were made during November 2005- December 2006. The collected samples were washed well and placed in sterile polythene bags and were brought to the laboratory. After the preliminary screening for marine fungi under stereomicroscope, the wood samples were incubated at room temperature. Periodical isolation of marine fungi from these wood materials were carried out for six months. Identifications of marine fungi were done using taxonomic keys [2, 26- 28]. The marine fungi identified are tabulated in Table 1.

\subsection{Presentation of data}

Percent frequency of occurrence and percent relative abundance of marine fungi of Kerala, Tamil Nadu and Pondicherry were calculated. Overall percent frequency of occurrence and percent relative abundance of marine fungi of South India was also calculated.

i) Percent frequency of occurrence (FO) = Number of isolates of a particular species divided by total number of wood samples supporting marine fungi $\times 100$.

On the basis of percentage occurrence, the marine fungi were classified as most frequent (occurring in more than $10 \%$ samples), frequent (in 5- $10 \%$ ), occasional (in $1-5 \%$ samples) and rare (in $<1 \%$ ).

ii) Percent relative abundance $(\mathrm{RA})=$ number of isolates of a particular species obtained divided by total number of fungal isolates $\times 100$.

Table 1. List of arenicolous marine fungi.

\begin{tabular}{|c|c|c|c|c|c|c|c|c|}
\hline \multirow{2}{*}{ Fungi } & \multicolumn{2}{|c|}{ Kerala } & \multicolumn{2}{|c|}{ Tamil Nadu } & \multicolumn{2}{|c|}{ Pondicherry } & \multicolumn{2}{|c|}{ South India } \\
\hline & FO & RA & FO & RA & FO & RA & FO & RA \\
\hline $\begin{array}{l}\text { Ascomycetes } \\
\text { Antennospora } \\
\text { quadricornuta } \\
\text { (Cribb et Cribb) }\end{array}$ & & & & & & & & \\
\hline $\begin{array}{l}\text { Johnson } \\
\text { Antennospora }\end{array}$ & 8.00 & 6.45 & & & & & 6.12 & 4.95 \\
\hline $\begin{array}{l}\text { salina Yusoff, Jones } \\
\text { et Moss }\end{array}$ & 2.67 & 2.15 & & & & & 2.04 & 1.65 \\
\hline
\end{tabular}


Table 1 (continued)

\begin{tabular}{|c|c|c|c|c|c|c|c|c|}
\hline $\begin{array}{l}\text { Arenariomyces } \\
\text { majusculus Kohlm } \\
\text { et Kohlm }\end{array}$ & 9.33 & 7.53 & & & & & 1.63 & 27.59 \\
\hline $\begin{array}{l}\text { Arenariomyces } \\
\text { parvulus Koch. }\end{array}$ & 2.67 & 2.15 & & & & & 7.14 & 5.79 \\
\hline $\begin{array}{l}\text { Arenariomyces } \\
\text { trifurcatus Hohnk }\end{array}$ & 5.33 & 4.30 & & & & & 4.08 & 3.30 \\
\hline $\begin{array}{l}\text { Ceriosporopsis } \\
\text { capillacea Kohlm }\end{array}$ & & & 0.66 & 0.54 & & & 0.51 & 0.41 \\
\hline $\begin{array}{l}\text { Ceriosporopsis } \\
\text { halima Barghoom } \\
\text { et Linder }\end{array}$ & 2.00 & 1.61 & & & & & 1.53 & 1.24 \\
\hline $\begin{array}{l}\text { Corollospora } \\
\text { angusta Nakagiri et } \\
\text { Tokura }\end{array}$ & 1.33 & 1.08 & 3.33 & 3.13 & 43.75 & 29.17 & 5.10 & 4.13 \\
\hline $\begin{array}{l}\text { Corollospora } \\
\text { colossa Nakagiri et } \\
\text { Tokura }\end{array}$ & 2.67 & 2.15 & & & & & 2.04 & 1.65 \\
\hline $\begin{array}{l}\text { Corollospora } \\
\text { filiformis Nakagiri } \\
\text { et Tokura }\end{array}$ & 15.33 & 12.37 & 3.33 & 3.13 & & & 12.24 & 9.12 \\
\hline $\begin{array}{l}\text { Corollospora } \\
\text { gracilis Nakagiri et } \\
\text { Tokura }\end{array}$ & & & & & 12.50 & 8.33 & 1.02 & 0.83 \\
\hline Corollospora indica & & & & & & & & \\
\hline $\begin{array}{l}\text { Prasannarai, } \\
\text { Ananda et Sridhar }\end{array}$ & & & 6.67 & 6.25 & 6.25 & 4.17 & 4.08 & 3.30 \\
\hline $\begin{array}{l}\text { Corollospora } \\
\text { luteola Nakagiri et } \\
\text { Tubaki }\end{array}$ & 4.00 & 4.30 & & & 12.50 & 8.33 & 1.53 & 1.24 \\
\hline $\begin{array}{l}\text { Corollospora } \\
\text { maritima } \\
\text { Werdermann }\end{array}$ & 8.00 & 6.45 & & & 20.00 & 18.75 & 7.14 & 5.79 \\
\hline $\begin{array}{l}\text { Corollospora } \\
\text { pseudopulchella } \\
\text { Nakagiri et Tokura } \\
\text { Corollospora }\end{array}$ & 9.33 & 5.38 & 13.33 & 12.50 & & & 2.05 & 1.65 \\
\hline $\begin{array}{l}\text { pulchella Kohlm. } \\
\text { Schmidt et Nair }\end{array}$ & 2.67 & 2.15 & & & & & 5.10 & 4.13 \\
\hline $\begin{array}{l}\text { Dryosphaera } \\
\text { tropicalis Kohlm et } \\
\text { Kohlm }\end{array}$ & 1.33 & 3.76 & 6.67 & 6.25 & 6.25 & 4.17 & 0.51 & 0.41 \\
\hline $\begin{array}{l}\text { Savoryella } \\
\text { appendiculata Hyde } \\
\text { et Jones }\end{array}$ & 2.67 & 2.15 & & & & & 2.05 & 1.65 \\
\hline
\end{tabular}


Table 1 (continued)

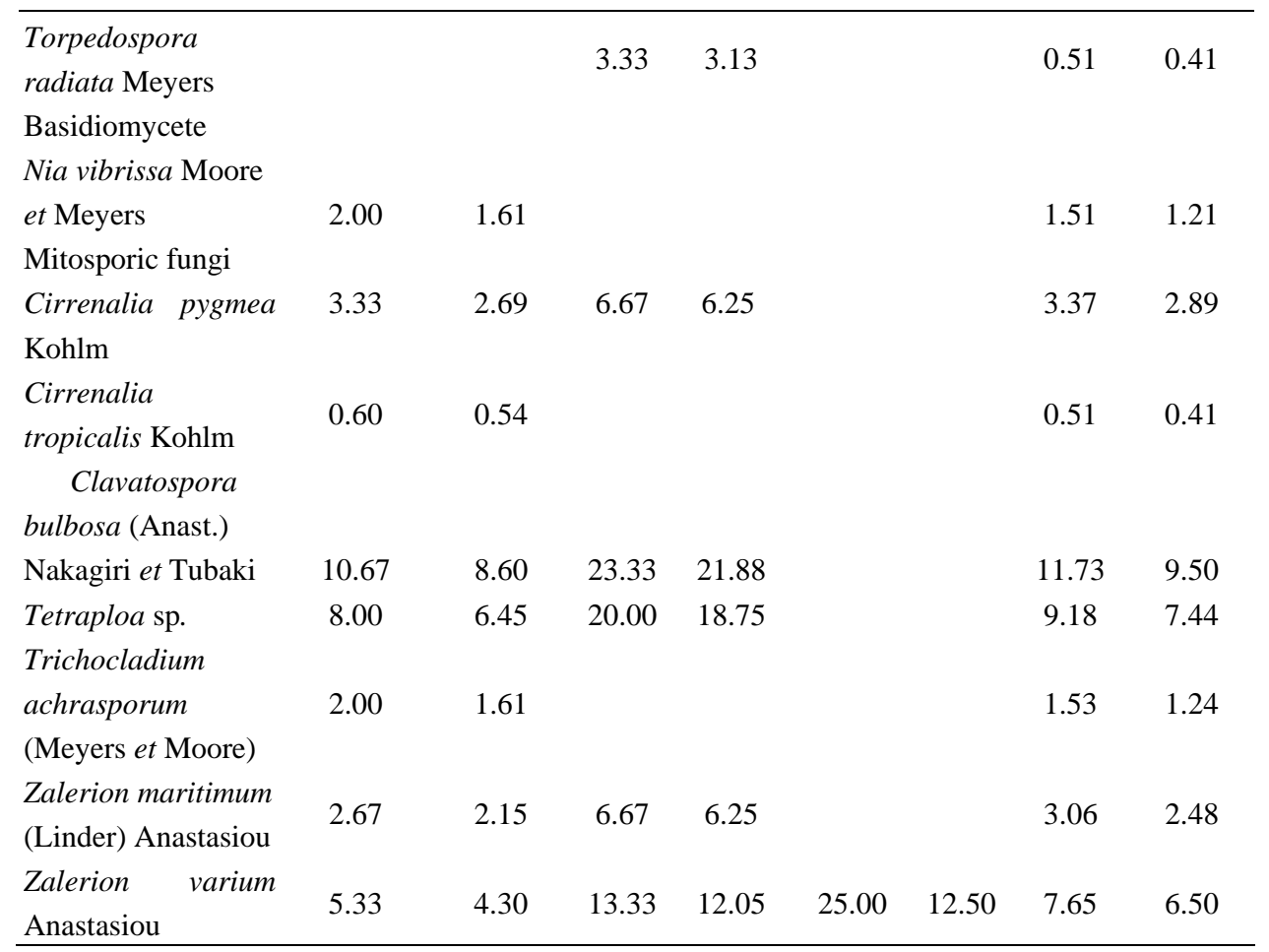

FO means percent frequency of occurrence and RA, percent relative abundance.

\section{Results and Discussion}

A total of 27 marine fungi were isolated during the course of the present study. These include 19 Ascomycetes, 1 Basidiomycete and 7 Mitosporic fungi. Maximum fungal composition was shown by Kerala (24) with 16 Ascomycetes, 1 Basidiomycete and 7 Mitosporic fungi and minimum by Pondicherry i.e. 7 with 6 Ascomycetes and 1 Mitosporic fungi. Tamil Nadu represented 12 arenicolous marine fungi with 7 Ascomycete and 5 Mitosporic fungi. Only three species, Corollospora angusta, Dryosphaera tropicalis and Zalerion varium were found common to all locations.

In terms of percent frequency of occurrence, from Kerala two species were most frequently obtained, seven species were recorded frequently, two species were occasionally encountered and twelve were rare. From Pondicherry, five species were most frequently isolated and two species were frequently obtained. From Tamil Nadu four species were most frequently and frequently obtained, three species were found occasionally while Ceriosporopsis capillacea was recorded in less than $1 \%$ of the samples. Overall percent frequency of occurrence from South India reveals that Corollospora filiformis and Clavatospora bulbosa were most frequent, Antennospora 
quadricornuta, Arenariomyces parvulus, Corollospora intermedia, C. maritima, C. pulchella, Tetraploa sp and Zalerion varium were frequent, 14 species were occasional while four species, Ceriosporopsis capillacea, Dryosphaera tropicalis, Torpedospora radiata and Cirrenalia tropicalis were rare in occurrence. Maximum frequency of occurrence and relative abundance value was obtained from Pondicherry followed by Tamil Nadu and minimum from Kerala.

Majority of fungi encountered were ascomycetes indicating their importance in this habitat. This is not unique to this study as the preponderance of ascomycetes over the other group of fungi in various marine habitats has been reported by other workers [26, $29,30]$. Ascomycetes appear to have evolved to take full advantage of marine habitat with their small fruit bodies, appendaged spores that may aid in dispersal and attachment and also to with stand fluctuating saline conditions. Arenicolous ascomycetes in general have small fruit bodies which are attached to sandy grains on woody substrates and have thick, hard and carbonaceous walls [2].

The present study supports the maximum number of arenicolous marine fungi reported so far [12, 13, 26, 31- 35]. Among them Ceriosporopsis capillacea, Dryosphaera tropicalis Savoryella appendiculata are new record for the fungi from Pondicherry; Corollospora colossa and Corollospora indica from Tamil Nadu and Corollospora gracilis from Kerala. The common species obtained in the present investigation is also distinct from earlier report. Corollospora maritima was recorded frequent from Seychelles [31], Corollospora pulchella from Brunei [32], Arenariomyces trifurcates and Clavatospora bulbosa from Mangalore coast, India [12], Corollospora maritima from west coast of India [13], Corollospora filiformis, Arenariomyces trifurcates and Antennospora quadricornuta from Kerala, India [26]. This could be attributed to a number of factors like $\mathrm{p}^{\mathrm{H}}$ and oceanic region, extent of salinity, nature of floor, position of intertidal region, availability and nature of hosts, exposure of the beach wood to the harsh dry conditions, number of samples examined and incubation period of the wood samples in the laboratory [13].

\section{Acknowledgements}

The authors are thankful to the Principal and Management of Sir Syed College, Taliparamba for providing facilities and also to D. A. E/B.R.N.S. for providing financial support.

\section{References}

1. P. S. Meadows and J.G. Anderson, Nature, 212, 1059 (1966). doi:10.1038/2121059a0

2. J. Kohlmeyer and E. Kohlmeyer, Marine mycology- The Higher fungi (Academic Press, New York, USA 1979).

3. G. Becker and J. Kohlmeyer, J. Timb. Ory. Deser. Asso. Ind. 4, 1 (1958).

4. S. Raghukumar, Kavaka, 1, 73 (1973).

5. S. Raghukumar, Trans Br Mycol Soc. 90, 627 (1988). doi:10.1016/S0007-1536(88)80068-8

6. B. D. Borse, Indian J. Mar. Sci. 17, 165 (1988). 
7. S. D. Patil and B. D.Borse, Indian Bot. Reptr. 1, 102 (1982).

8. S. D. Patil and B. D.Borse, Indian Bot. Reptr. 2, 56 (1983).

9. K. B. Patil and B. D.Borse, Geobios, 28, 41 (2001).

10. D. R. Ravikumar and B. P. R. Vittal, Kavaka. 15, 99 (1987). doi:10.1016/S0953-7562(09)81250-1

11. D. R. Ravikumar and B. P. R. Vittal, Mycol. Res. 95, 370 (1991).

12. K. R. Sridhar and K. M. Karveriappa, Mahasagar. 24, 63 (1991).

13. K. Prasannarai and K. R. Sridhar, Curr. Sci. 81, 304 (2001).

14. K. Prasannarai and K. R. Sridhar, Indian J. Mar. Sci. 32, 329 (2003).

15. K. Ananda, K. Prasannarai, and K. R. Sridhar, Indian J. Mar. Sci., 27, 233 (1998).

16. K. Prasannarai, K. Ananda, and K. R. Sridhar, J. Environ. Biol. 21, 235 (2001).

17. V. V. Sarma and B. P. R.Vittal, Fungal diversity. 6,115 (2001).

18. G. L. Maria and K. R. Sridhar, Curr. Sci. 3, 1573 (2002).

19. K. R. Sridhar, in Microbial Diversity: Current perspectives and potential applications ed. T. Satyanarayana and B. N. Johri (I. K. International Pvt. Ltd., New Delhi, 2005), pp 129 -148.

20. G. R .Nambiar and K. Raveendran, J. Mar. Atmos. Res. 2, 29 (2007).

21. G. R .Nambiar and K. Raveendran, Eco-chronicle, 3, 47 (2008a).

22. G. R Nambiar and K. Raveendran, Seaweed Res. Utiln. 30, 55 (2008b).

23. G. R. Nambiar, P. V. Pratheesh, and K. Raveendran, Seaweed Res. Utiln., 28, 55 (2006).

24. G. R. Nambiar, C. A. Jaleel, and K. Raveendran, C. R. Biol. 331, 1 (2008). doi:10.1016/j.crvi.2007.10.009

25. G. R. Nambiar, C. A. Jaleel, Z. Chanxing, and K. Raveendran, C.R. Biol. 331, 475 (2008b). doi:10.1016/j.crvi.2008.03.008

26. K. Raveendran and P. Manimohan, Marine fungi of Kerala - A preliminary floristic and ecological study (Malabar Natural Historical Society, Calicut, Kerala, India, 2007).

27. J. Kohlmeyer and Volkmann Kohlmeyer, Botanica Marina. 34, 1 (1991). doi:10.1515/botm.1991.34.1.1

28. K. D.Hyde and V. V. Sarma, in Marine Mycology - A Practical Approach, eds. K. D. Hyde and S.B. Pointing (Fungal Diversity Press, Hong Kong 2000) pp. 205-270.

29. J. Kohlmeyer, Mar. Ecol. 5, 329 (1984). doi:10.1111/j.1439-0485.1984.tb00130.x

30. K. D. Hyde, Bot. J. Linn. Soc. 98,135 (1988). doi:10.1111/j.1095-8339.1988.tb01700.x

31. K. D. Hyde, in Biology of Marine fungi, ed. S.T. Moss (Cambridge Univ. Press, Cambridge, 1986) pp. 311-322.

32. K. D. Hyde, Can. J. Bot. 67, 3078 (1989). doi:10.1139/b89-386

33. A. Nakagiri, IFO Res. Commun. 14, 52 (1989).

34. R. Tokura, Trans. Mycol. Soc. Jpn. 23, 423 (1982).

35. B. D. Borse and N. B. Pawar, J. Adv. Sci. and Tech. 8, 43 (2005). 